\title{
Thermonema lapsum gen. nov., sp. nov., a Thermophilic Gliding Bacterium
}

\author{
J. ANDREW HUDSON,* KARIN M. SCHOFIELD, HUGH W. MORGAN, AND ROY M. DANIEL \\ Microbial Biochemistry and Biotechnology Unit, University of Waikato, Private Bag, Hamilton, New Zealand
}

\begin{abstract}
We previously reported the isolation of five strains of a thermophilic gliding organism. These strains are described here as a new genus and species, Thermonema lapsum. The isolates can be readily distinguished from other thermophilic gliding bacteria as they are apparently unicellular aerobic filaments that grow optimally at $60^{\circ} \mathrm{C}$. Their cell walls are similar in ultrastructure to those of gram-negative cells, but they are susceptible to penicillin G. Our isolates can be grown on a fully defined medium containing amino acids. Oxidationversus-fermentation tests indicate that deamination takes place. The type strain, strain 23/9, has been deposited with the American Type Culture Collection as strain ATCC 43542.
\end{abstract}

A number of nonphotosynthetic gliding bacteria have been isolated from hot spring environments, although none described to date has a temperature optimum above $60^{\circ} \mathrm{C}$. Apart from cyanobacteria, two photosynthetic gliding organisms have been isolated from these environments. The first to be described was Chloroflexus aurantiacus (7). This organism has a temperature optimum of 52 to $60^{\circ} \mathrm{C}$ and can grow photoautotrophically or photoheterotrophically under illuminated anaerobic conditions and heterotrophically in both light and dark when it is grown aerobically. Heliothrix oregonensis (8) is unique since it contains only one bacteriochlorophyll, bacteriochlorophyll $a$. This organism has not been reported to grow in pure culture, but uptake studies (8) have shown that the temperature optimum is around 40 to $45^{\circ} \mathrm{C}$. Sequence comparisons of $5 \mathrm{~S}$ ribosomal ribonucleic acids indicate that members of the genus Heliothrix are most closely related to Chloroflexus species (8).

Herpetosiphon geysericola (6) was isolated from a hot spring algal mat, but this organism was grown at 25 to $30^{\circ} \mathrm{C}$ in subsequent studies (10). Another obligately aerobic heterotroph, Isosphaera pallida (2), forms intercalary buds to achieve cell division and can grow at temperatures up to $55^{\circ} \mathrm{C}$.

In a previous report (14) we described five new isolates from New Zealand hot springs which exhibit gliding motility. The cells of these strains are long filaments which have terminal swellings, and the organisms have an optimum temperature for growth of $60^{\circ} \mathrm{C}$. In the work described in this paper we added to the previous data, and our results support a proposal to place these strains in a new genus, Thermonema, with all of the isolates belonging to one species, Thermonema lapsum. The type strain has been deposited with the American Type Culture Collection, and one other strain, 19/15, which was isolated from a different hot pool, has also been deposited with the American Type Culture Collection as strain ATCC 43543.

\section{MATERIALS AND METHODS}

Strains used. We used four strains whose isolation has been described previously (14); these strains were strains $23 / 9^{\mathrm{T}}$ ( $\mathrm{T}=$ type strain), $23 / 5,19 / 4$, and $19 / 15$.

Media and culture conditions. Routine maintenance was on Castenholz medium D under previously described conditions (14).

\footnotetext{
* Corresponding author.
}

To test for hydrolysis of insoluble substrates, agar overlay plates were prepared as reported previously for Thermus taxonomic tests (4). The upper layer of the overlay contained Sigmacell 50, keratin, or starch at a concentration of $4 \mathrm{~g} /$ liter or colloidal chitin, prepared as described by Hsu and Lockwood (3), at a concentration of 3 g/liter.

The fully defined basal medium, which was used to evaluate the substrates utilized, was a modification of American Type Culture Collection medium 284; it contained (per liter) $0.1 \mathrm{~g}$ of $\mathrm{MgSO}_{4} \cdot 7 \mathrm{H}_{2} \mathrm{O}, 0.1 \mathrm{~g}$ of $\mathrm{KNO}_{3}, 0.1 \mathrm{~g}$ of $\mathrm{CaCl}_{2} \cdot 2 \mathrm{H}_{2} \mathrm{O}, 0.1 \mathrm{~g}$ of sodium $\beta$-glycerophosphate, and $1 \mathrm{~g}$ of tris(hydroxymethyl)aminomethane buffer, as well as a vitamin solution (17), trace elements, and $\mathrm{FeCl}_{3}$ as described by Ramaley and Hixson (11). The medium was dispensed in 9-ml volumes, and $1-\mathrm{ml}$ additions of sterile stock solutions were made as required.

A synthetic amino acid mixture was prepared as described by Slijkhuis (15). The stock solution which we used contained (per $100 \mathrm{ml}$ ) $470 \mathrm{mg}$ of aspartic acid, $210 \mathrm{mg}$ of threonine, $320 \mathrm{mg}$ of serine, $960 \mathrm{mg}$ of glutamic acid, $690 \mathrm{mg}$ of proline, $150 \mathrm{mg}$ of glycine, $200 \mathrm{mg}$ of alanine, $220 \mathrm{mg}$ of valine, $90 \mathrm{mg}$ of methionine, $110 \mathrm{mg}$ of isoleucine, $250 \mathrm{mg}$ of leucine, $70 \mathrm{mg}$ of tyrosine, $140 \mathrm{mg}$ of phenylalanine, $350 \mathrm{mg}$ of lysine, $100 \mathrm{mg}$ of histidine, and $150 \mathrm{mg}$ of arginine. The mixture was filter sterilized and added to the medium in the proportion described above.

Hugh-Leifson oxidation-versus-fermentation tests were carried out as described by Smibert and Krieg (16), using filter-sterilized glucose, maltose, or sucrose at a final concentration of $0.5 \%(\mathrm{wt} / \mathrm{vol})$.

Ultrastructure. Thin sections and negatively stained grids of strain $23 / 9^{\mathrm{T}}$ were prepared for electron microscopy, stained, and examined by using a Philips model EM400 electron microscope as previously described (5).

Antibiotic inhibition. Antibiotic dilutions were prepared to give final concentrations of 100,10 , and $1 \mu \mathrm{g} / \mathrm{ml}$. Filtersterilized solutions were added to Castenholz medium D (11) broth, and inoculation was with $0.1 \mathrm{ml}$ of a 24-h broth culture. Growth was recorded after $24 \mathrm{~h}$ of incubation at $60^{\circ} \mathrm{C}$.

\section{RESULTS AND DISCUSSION}

Table 1 shows a comparison of strain $23 / 9^{\mathrm{T}}$ with other gliding bacteria which have some of the same characteristics. Thermonema lapsum can readily be distinguished from these other organisms by a number of criteria derived from 
TABLE 1. Comparison of Thermonema lapsum with other filamentous gliding bacteria ${ }^{a}$

\begin{tabular}{|c|c|c|c|c|c|c|c|c|}
\hline Taxon & $\begin{array}{c}\mathrm{G}+\mathrm{C} \text { content } \\
(\mathrm{mol} \%)\end{array}$ & Optimum pH & $\begin{array}{l}\text { Optimum temp } \\
\left({ }^{\circ} \mathrm{C}\right)\end{array}$ & Anaerobiosis & Autotrophism & Carotenoids & $\begin{array}{l}\text { Cell length } \\
(\mu \mathrm{m})\end{array}$ & $\begin{array}{c}\text { Cell width } \\
(\mu \mathrm{m})\end{array}$ \\
\hline Thermonema lapsum & 47 & 6.5 & 60 & - & - & + & $60+$ & $0.25-0.3$ \\
\hline C. aurantiacus & 55 & $7.6-8.4$ & $52-60$ & $F^{b}$ & $\mathbf{F}$ & + & $2-6$ & $0.6-0.7$ \\
\hline Heliothrix oregonensis & $\mathrm{NA}^{c}$ & NA & $40-45$ & - & + & + & 10 & 1.5 \\
\hline I. pallida & 62.2 & $7.8-8.8$ & 41 & - & - & + & $2.5-3$ & $2.5-3$ \\
\hline Flexibacter spp. & 48 & NA & Mesophilic & - & - & - & Variable & $<1$ \\
\hline
\end{tabular}

a Data from references $2,7-9,12$, and 14 .

${ }^{b}$ F, Facultative

c NA, Not available.

the data presented here and by criteria described previously (14).

Both C. aurantiacus and Heliothrix oregonensis are photosynthetic organisms. $C$. aurantiacus has a higher guanineplus-cytosine $(\mathrm{G}+\mathrm{C})$ content, is a facultative anaerobe, and has a higher optimum $\mathrm{pH}$ than the strains described here. Heliothrix oregonensis has not been grown in pure culture and has a considerably lower optimum temperature than Thermonema lapsum. The obligate aerobe $I$. pallida has a much higher $\mathrm{G}+\mathrm{C}$ content, has a lower optimum temperature, has a distinctive morphology, and grows at higher $\mathrm{pH}$ values than Thermonema lapsum.

The members of the genus Thermus can also have a filamentous cell morphology, and one species, Thermus filiformis (5), consistently produces filaments. However, the isolates of Thermonema lapsum differ from Thermus species in $\mathrm{G}+\mathrm{C}$ content, aminopeptidase reaction, motility, and optimum $\mathrm{pH}$ and temperature. In addition, while Thermus species grow on a range of monosaccharides, amino acids, and tricarboxylic acid cycle intermediates (5), it was noted at an early stage that growth of Thermonema lapsum does not occur on carbohydrates and that peptone appears to be a nutritional requirement (14). To confirm this, a range of carbon sources were subsequently tested by adding them to the basal medium. Medium containing Casamino Acids was used as a positive control. Only Casamino Acids and synthetic amino acid mixtures supported growth of Thermonema lapsum.

Incubation under both the aerobic and anaerobic conditions of the Hugh-Leifson test resulted in no acid formation. Instead, there was a pronounced alkalinization of the medium, suggesting that deamination was occurring. These results are consistent with the nutritional data reported above. Strains of the genus Thermus show no reaction in such tests (1).

Figure 1 shows the cell wall structure of strain $23 / 9^{\mathrm{T}}$. The cell wall of this organism is similar in ultrastructure to the cell walls of gram-negative organisms. In negatively stained preparations (Fig. 2) there was evidence of a slime or capsule layer, which is consistent with this organism being a gliding bacterium. No septa were observed in a number of thin sections prepared on different occasions so we concluded that each of the filaments is probably unicellular.

The Gram reaction, cell wall structure, and aminopeptidase test all indicate that Thermonema lapsum is a gramnegative organism, whereas members of the genus Thermus have many biochemical characteristics similar to those of gram-positive bacteria (5).

All of the Thermonema lapsum strains which we tested were susceptible to penicillin $G$ and erythromycin at the lowest concentration tested, while all of the strains were resistant to nalidixic acid at a concentration of $100 \mu \mathrm{g} / \mathrm{ml}$. The strains grew in the presence of $1 \mu \mathrm{g}$ of vancomycin per $\mathrm{ml}, 10 \mu \mathrm{g}$ of kanamycin per $\mathrm{ml}$, and $10 \mu \mathrm{g}$ of D-cycloserine per $\mathrm{ml}$, and all but one strain grew in the presence of $1 \mu \mathrm{g}$ of neomycin per $\mathrm{ml}$. The susceptibility to penicillin $\mathrm{G}$ is shared by Thermus species (5), while the newly described strains are more resistant to kanamycin than members of the genus Thermus (5). The results for all of the Thermonema lapsum strains which we tested were very similar, supporting the conclusion that these organisms are closely related phenotypically.

The strains which we isolated might also represent thermophilic variants of an otherwise mesophilic genus. Of the gliding bacteria, Thermonema lapsum most closely resembles the members of the genus Flexibacter (12), but it differs in a number of important features which are used to define the mesophilic genus.

Unlike members of the genus Flexibacter, the new strains do not produce flexirubin (14) and do not show a change in morphology from filaments to rods as the age of the culture increases. The gliding motility of Thermonema lapsum is not "agile" as reported for Flexibacter species in young cultures. The cell wall of Flexibacter polymorphous is distinctive, with the production of "goblet-like" structures on the outer surface of the cell envelope (13). Thin sections of Thermonema lapsum showed no such structures; and the cell walls had a gram-negative appearance and, as such, were similar to the cell walls of another Flexibacter sp. strain, strain FS-1 (9). Unlike many members of the order Cytophagales, the strains of Thermonema lapsum which we tested were unable to hydrolyze the polymers tested. After $72 \mathrm{~h}$ of incubation no zones of hydrolysis were noted on cellulose or starch. None of the strains grew on medium containing chitin or keratin.

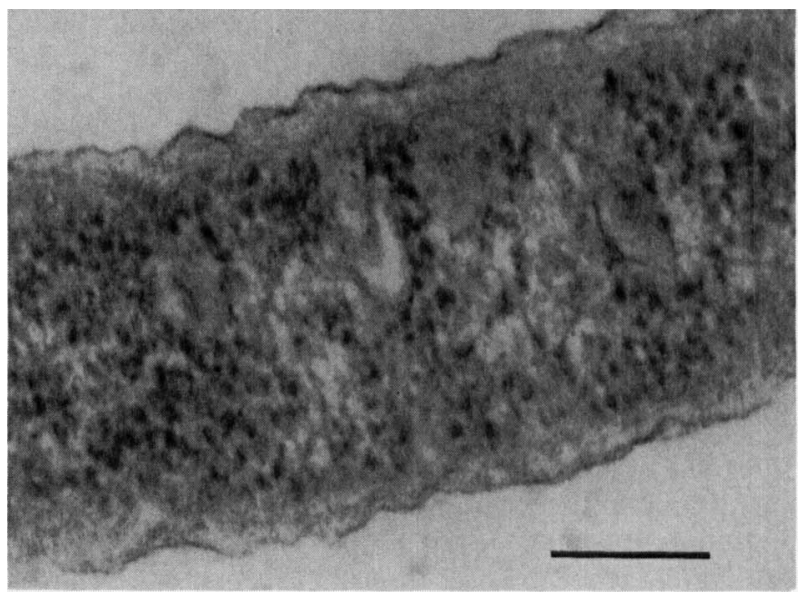

FIG. 1. Thin-section electron micrograph of Thermonema lapsum cell wall showing the gram-negative structure. Bar $=0.1 \mu \mathrm{m}$. 


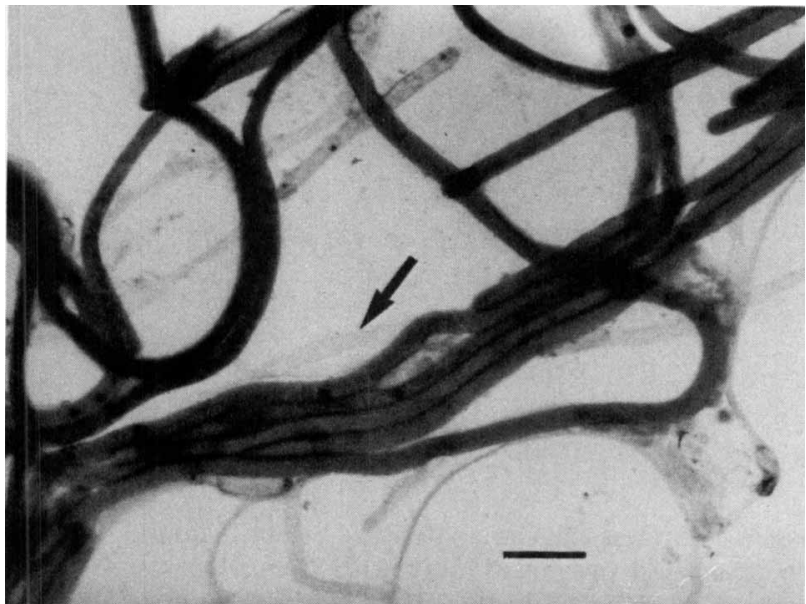

FIG. 2. Negatively stained electron micrograph of Thermonema lapsum showing possible slime or capsular material (arrow). Bar $=$ $1 \mu \mathrm{m}$.

These differences from known mesophilic and thermophilic gliding bacteria lead us to propose a new genus and species to contain the newly described isolates.

Thermonema gen. nov. Thermonema (Ther.mo.ne'ma. Gr. adj. thermos, hot; Gr. n. nema, a thread; M.L.neut.n. Thermonema, a thermophilic thread). Apparently unicellular filaments usually around $60 \mu \mathrm{m}$ long and 0.25 to $0.3 \mu \mathrm{m}$ in diameter. Aerobic. Gram negative and aminopeptidase positive. Motile by gliding. Cells possess acetone-extractable pigments with an absorbance peak at $450 \mathrm{~nm}$. Oxidase and catalase positive. Thermophilic, growing optimally at $60^{\circ} \mathrm{C}$ and at temperatures up to $70^{\circ} \mathrm{C}$ at neutral $\mathrm{pH}$. The type species is Thermonema lapsum.

Thermonema lapsum sp. nov. Thermonema lapsum (lap'sum. L. n. lapsum glide). The $\mathrm{G}+\mathrm{C}$ content of type strain $23 / 9$ is $47 \mathrm{~mol} \%$. All five strains which we tested are $\alpha$ and $\beta$-galactosidase negative and deoxyribonuclease positive. All strains are proteolytic. No strain hydrolyzes cellulose or starch.

The following basal medium supplements do not support growth: acetate, L-alanine, casein, L-cystine, galactose, gelatin, gluconate, glucose, inositol, lactose, L-malate, L-proline, propan-1-ol, pyruvate, rhamnose, ribose, skim milk, sorbitol, succinate, sucrose, and yeast extract (all at concentrations of $1 \mathrm{~g} /$ liter) plus the glutamate amino acid family (glutamate, proline, and arginine) (all at concentrations of $3.3 \mathrm{~g} /$ liter).

The following basal medium supplements support growth: Casamino Acids (1, 10, and $25 \mathrm{~g} /$ liter), amino acid mixture 1 (as described in Materials and Methods), and amino acid mixture 2 (the same as amino acid mixture 1 except that it lacks methionine, phenylalanine, tyrosine, and leucine).

Type strain 23/9 and one other strain, strain 19/15, were isolated from New Zealand hot springs and have been deposited with the American Type Culture Collection as strains ATCC 43532 and ATCC 43543, respectively.

\section{ACKNOWLEDGMENTS}

This work was partly funded by the Development Finance Corporation of New Zealand.

We thank Yvonne Casey, Carol Brockelsby, and Helen Littleworth for their technical assistance and Colin Monk for preparation and examination of specimens by electron microscopy. The Meat Industry Research Institute of New Zealand kindly provided electron microscope facilities.

\section{LITERATURE CITED}

1. Degryse, E., N. Glansdorff, and A. Pierard. 1978. A comparative analysis of extreme thermophilic bacteria belonging to the genus Thermus. Arch. Microbiol. 117:189-196.

2. Giovannoni, S. J., E. Schabtach, and R. W. Castenholz. 1987. Isosphaera pallida, gen. and comb. nov., a gliding, budding eubacterium from hot springs. Arch. Microbiol. 147:276-284.

3. Hsu, S. C., and J. L. Lockwood. 1975. Powdered chitin as a selective medium for enumeration of actinomycetes in water and soil. Appl. Microbiol. 29:422-426.

4. Hudson, J A., H. W. Morgan, and R. M. Daniel. 1986. A numerical classification of some Thermus isolates. J. Gen. Microbiol. 132:531-540.

5. Hudson, J. A., H. W. Morgan, and R. M. Daniel. 1987. Thermus filiformis sp. nov., a filamentous caldoactive bacterium. Int. J. Syst. Bacteriol. 37:431-436.

6. Lewin, R. A. 1970. New Herpetosiphon species (Flexibacterales). Can. J. Microbiol. 16:517-520.

7. Pierson, B. K., and R. W. Castenholz. 1974. A phototrophic gliding filamentous bacterium of hot springs, Chloroflexus aurantiacus, gen. and sp. nov. Arch. Microbiol. 100:5-24.

8. Pierson, B. K., S. J. Giovannoni, D. A. Stahl, and R. W. Castenholz. 1985. Heliothrix oregonensis gen. nov., sp. nov., a phototrophic filamentous gliding bacterium containing bacteriochlorophyll a. Arch. Microbiol. 142:164-167.

9. Poos, J. C., F. R. Turner, D. White, G. D. Simon, K. Bacon, and C. T. Russel. 1972. Growth, cell division, and fragmentation in a species of Flexibacter. J. Bacteriol. 112:1387-1395.

10. Quinn, G. R., and V. B. D. Skerman. 1980. Retrofilation and tumulation by strains of Herpetosiphon species. Curr. Microbiol. 3:345-348.

11. Ramaley, R. F., and J. Hixson. 1970. Isolation of a nonpigmented, thermophilic bacterium similar to Thermus aquaticus. J. Bacteriol. 103:527-528.

12. Reichenbach, H., and M. Dworkin. 1981. The order Cytophagales (with addenda on the genera Herpetosiphon, Saprospira and Flexithrix), p. 356-379. In M. P. Starr, H. Stolp, H. G. Truper, A. Balows, and H. G. Schlegel (ed.), The prokaryotes. A handbook on habitats, isolation and identification of bacteria. Springer-Verlag KG, Berlin.

13. Ridgway, H. F., R. M. Wagner, W. T. Dawsey, and R. A. Lewin. 1975. Fine structure of the cell envelope layers of Flexibacter polymorphous. Can. J. Microbiol. 21:1733-1750.

14. Schofield, K. M., J. A. Hudson, H. W. Morgan, and R. M. Daniel. 1987. A thermophilic gliding bacterium from New Zealand hot springs. FEMS Microbiol. Lett. 40:169-172.

15. Slijkhuis, H. 1983. Microthrix parvicella, a filamentous bacterium isolated from activated sludge: cultivation in a chemically defined medium. Appl. Environ. Microbiol. 46:832-839.

16. Smibert, R. M., and N. R. Krieg. 1981. General characterization, p. 409-443. In P. Gerhardt, R. G. E. Murray, R. N. Costilow, E. W. Nester, W. A. Wood, N. R. Krieg, and G. B. Phillips (ed.), Manual of methods for general bacteriology. American Society for Microbiology, Washington, D. C.

17. Wolin, E. A., M. J. Wolin, and R. S. Wolfe. 1963. Formation of methane by bacterial extracts. J. Biol. Chem. 238:2882-2886. 